\title{
Through a Cuban Lens
}

A sight for sore eyes. Keep your eye on the ball. Left in the dark. Look before you leap. Seeing is believing. Watch your step...Our language abounds in visual metaphors, reflecting the importance of vision for our interactions with the environment, for our ability to understand, appreciate, and negotiate life itself.

In fact, over $80 \%$ of our sensory input is visual, the starting place for what may be the best example of the bio-psychosocial paradigm for defining health and illness. Articles in this issue of MEDICC Review range through that complex spectrum, devoting pages to vision loss, surgical correction and rehabilitation; development and social inclusion of visually disabled persons; and the enigmas of vision-related epidemics in Cuba.

The proportion of avoidable blindness in Cuba is estimated to be among the lowest in the Americas.[1] Among Havana's 2.2 million people, the prevalence of all-cause blindness in the over50 age group was $2.3 \%$ in 2005,[2] and a 2004 study indicated that some $11.6 \%$ of the city's population had low vision.[1] Since Cuba's population is rapidly aging, the numbers of visually impaired can only be expected to increase. But no recent findings outside the capital have been published, supporting Pedro Más's argument for more local research on these and other agerelated conditions (Addressing Cuba's Aging Population:Why Epimapping Needs to Go Local).

At the biological end of the spectrum, two promising young Cuban researchers present work on surgeries to prevent amblyopia, the main cause of monocular vision loss in adults (Improved Visual Acuity after Frontalis Sling Surgery for Simple Congenital Ptosis and Results of Surgery for Congenital Esotropia).

\section{$87 \%$ of the world's 314 million visually-impaired people live in developing countries}

Issues of rights, protection, development and social inclusion for visually-disabled persons are explored in Visually-impaired Children in Havana: Challenges of Education, Rehabilitation and Inclusion and A Cuban NGO Perspective on Disabilities. An interview with prominent Cuban neuro-ophthalmologist Dr Rosaralis Santiesteban highlights lessons from the Cuban epidemic neuropathy of the 1990s and unravels the mystery surrounding similar outbreaks a century earlier (In the Eye of the Cuban Epidemic Neuropathy Storm).

The WHO estimates that $87 \%$ of the world's 314 million visuallyimpaired people live in developing countries. The organization also notes that some $85 \%$ of visual impairment is avoidable; correction of refractive errors alone could give normal vision to more than 12 million children.[3] Since 2004, part of Cuba's international health cooperation has been an ambitious vision restoration program, involving direct delivery of care, surgeries and follow-up, as well as training and technology transfer. The Spring 2008 issue of MEDICC Review provides a comprehen- sive look at that program in the Americas and Africa by senior editor Conner Gorry. The current issue-published one year after the devastating earthquake in Haiti-carries another of her international cooperation reports, this time an update on the Cuban medical team's work in earthquake recovery and efforts to confront Haiti's cholera epidemic (Haiti One Year Later: Cuban Medical Team Draws on Experience and Partnerships).

Two original research papers touch on noncommunicable chronic diseases (Clinical and Epidemiological Profile of Diabetes Mellitus in Pregnancy, Isle of Youth, 2008 and Introduction of Imatinib as First-line Treatment for Chronic Myeloid Leukemia in Cuba). The chronic-disease theme will also be the main focus of our October issue, following the UN high-level meeting to galvanize action, aimed at slowing the global epidemic of these conditions.

This issue's reprint is an article from the Revista Cubana de Farmacia analyzing two decades of Cuba's experience in building clinical trials capacity for drug and medical-device evaluation (The National Clinical Trials Coordinating Center: Emergence, Evolution, and Main Results).

Looking ahead again, the theme for our April issue is HIV/ AIDS in Cuba, and will include inauguration of the journal's Lessons from the Field section. In July we will open our pages to both Cuban and international authors to shed light on efforts to ensure universal health care by developing-country health systems.

Finally, MEDICC Review has been accepted and will soon be indexed in the Public Health Collection of SciELO, an openaccess initiative for Latin America and the Caribbean supported by BIREME (Brazil) and PAHO/WHO. Scores of collaborators have made this possible, including the journal's peer reviewers for 2010 , who are recognized in this issue.

Thus, we begin 2011 expressing our gratitude to all-Editorial Board, collaborators, reviewers and readers-for your continued support. And a special thanks to the researchers and health professionals whose work has contributed to improving equity as well as science. -1 -

\section{The Editors}

1. Hans Limburg H, Barria von-Bischhoffshausen F, Gomez P, Silva JC, Foster A. Review of recent surveys on blindness and visual impairment in Latin America. Br J Ophthalmol. 2008;(92):315-319.

2. Cabrera Martínez A, Río Torres M, Hernández Silva E, Padilla González $\mathrm{CM}$. Prevalencia de ceguera y limitación visual severa en personas mayores de 50 años de Ciudad de La Habana. Rev Cubana Oftalmol [Internet]. 2007 Dec [cited 10 Jan 2011];20(2). Available at: http://scielo.sld.cu/scielo. php?script=scie_arttext\&pid=S0864-21762007000200011\&Ing=es

3. World Health Organization. Fact Sheet No, 282: Visual impairment and blindness. Geneva: WHO; 2009. 